Hydrol. Earth Syst. Sci., 17, 1963-1974, 2013

www.hydrol-earth-syst-sci.net/17/1963/2013/

doi:10.5194/hess-17-1963-2013

(C) Author(s) 2013. CC Attribution 3.0 License.

\title{
Impacts of soil-aquifer heat and water fluxes on simulated global climate
}

\author{
N. Y. Krakauer ${ }^{1}$, M. J. Puma ${ }^{2}$, and B. I. Cook ${ }^{2}$ \\ ${ }^{1}$ Department of Civil Engineering and NOAA-CREST, The City College of New York, New York, New York, USA \\ ${ }^{2}$ NASA Goddard Institute for Space Studies, New York, New York, USA
}

Correspondence to: N. Y. Krakauer (nkrakauer@ccny.cuny.edu)

Received: 4 January 2013 - Published in Hydrol. Earth Syst. Sci. Discuss.: 25 January 2013

Revised: 19 April 2013 - Accepted: 23 April 2013 - Published: 23 May 2013

\begin{abstract}
Climate models have traditionally only represented heat and water fluxes within relatively shallow soil layers, but there is increasing interest in the possible role of heat and water exchanges with the deeper subsurface. Here, we integrate an idealized $50 \mathrm{~m}$ deep aquifer into the land surface module of the GISS ModelE general circulation model to test the influence of aquifer-soil moisture and heat exchanges on climate variables. We evaluate the impact on the modeled climate of aquifer-soil heat and water fluxes separately, as well as in combination. The addition of the aquifer to ModelE has limited impact on annual-mean climate, with little change in global mean land temperature, precipitation, or evaporation. The seasonal amplitude of deep soil temperature is strongly damped by the soil-aquifer heat flux. This not only improves the model representation of permafrost area but propagates to the surface, resulting in an increase in the seasonal amplitude of surface air temperature of $>1 \mathrm{~K}$ in the Arctic. The soil-aquifer water and heat fluxes both slightly decrease interannual variability in soil moisture and in landsurface temperature, and decrease the soil moisture memory of the land surface on seasonal to annual timescales. The results of this experiment suggest that deepening the modeled land surface, compared to modeling only a shallower soil column with a no-flux bottom boundary condition, has limited impact on mean climate but does affect seasonality and interannual persistence.
\end{abstract}

\section{Introduction}

The land-surface components of global climate models (GCMs) have typically represented water and heat storage as occurring only in a surface layer $1-5 \mathrm{~m}$ deep (Manabe, 1969; Koster and Suarez, 1996; Milly and Shmakin, 2002; Essery et al., 2003; Dickinson et al., 2006; Schmidt et al., 2006). However, deeper aquifers that contain groundwater form a critical and depleting portion of the exploitable water resource in many areas (Siebert et al., 2010). These aquifers can exchange moisture with shallower soil layers, and can also be tapped by plant roots directly during dry periods (Fan and Miguez-Macho, 2010). Heat exchange beneath the soil column affects the seasonal cycle of soil temperature and its response time to global warming, which is particularly important for modeling permafrost processes (Nicolsky et al., 2007; Alexeev et al., 2007).

In view of these considerations, a number of studies in recent years have coupled models of deep water and heat storages with models of land-surface and atmosphere processes. Many published studies have worked in local to regional domains and over timescales of days to months. For example, Maxwell et al. (2007) showed that including groundwater resulted in more realistic spatial soil moisture variability in an Oklahoma watershed which, in turn, affected local atmospheric convection and boundary layer height over the short ( $36 \mathrm{~h}$ ) study period. Regional model studies by Anyah et al. (2008) and by Jiang et al. (2009) both found that groundwater storage and flow tends to increase available soil moisture and hence warm-season evaporation rates in the semiarid 
central and western United States, with impacts on simulated seasonal temperature and precipitation.

Representations of subsurface water on a global scale have mostly been tested in the Community Land Model (CLM) developed by the National Center for Atmospheric Research. The new versions 3.5 and 4.0 of CLM include such a representation (Oleson et al., 2008; Lawrence et al., 2011), based on the SIMGM model of Niu et al. (2007). In SIMGM, an unconfined aquifer is parametrized as a single deep layer underlying the model soil layers and exchanging water with them, as well as contributing to runoff. Inclusion of this deep layer improved the large dry bias in previous versions of CLM caused by too-quick drainage and insufficient soil water capacity (Bonan and Levis, 2006; Stöckli et al., 2008; Pan et al., 2008; Choi and Liang, 2010). The aquifer in CLM does not exchange heat with the shallower soil layers. Instead, there is a separate representation of deep bedrock layers for heat transfer (Lawrence et al., 2008). This separation between heat and water flux is unphysical (since the "deep bedrock" is assumed to occupy the same physical space as the "aquifer" yet not interact with it), and energy conservation is problematic since the aquifer temperature is not tracked as a state variable. Lo and Famiglietti (2011) showed that the wetter soil resulting from the aquifer in CLM 3.5 leads to significant changes in simulated global climate when CLM is coupled with the Community Atmosphere Model (CAM) 3.5. Global land evaporation increased by $9 \%$ and global land precipitation by $3 \%$, with much larger changes over particular regions and seasons - for example, over central North America summer precipitation increased by some $25 \%$. Lo and Famiglietti (2011) discuss the changes in atmospheric water transport that lead to these precipitation responses.

Here, we report on the impacts of including a simple aquifer parametrization in a different atmospheric general circulation model (GCM), the Goddard Institute for Space Studies (GISS) "ModelE". Unlike most previous studies, our experiments allow us to consider the impacts of aquifer-soil heat and water fluxes separately as well as in combination in an idealized but physically consistent (mass and energy conserving) framework. This study builds on previous work investigating soil moisture feedbacks on climate in ModelE (Krakauer et al., 2010), which found that soil moisture dynamics affected the persistence and intercorrelation of climate variables such as precipitation, evaporation, and surface air temperature. Our main scientific goal in this paper is to examine the impact of aquifer heat and water exchanges on the mean climate as well as on the seasonality and interannual variability of soil temperature and soil moisture and of climate variables, such as evaporation, precipitation, and surface air temperature which respond to soil conditions.

\section{Methods}

\subsection{ModelE}

Our modeling experiments were conducted with the Goddard Institute for Space Studies (GISS) ModelE, a stateof-the-art atmosphere GCM, run at a resolution of $2^{\circ}$ latitude by $2.5^{\circ}$ longitude (Schmidt et al., 2006; Hansen et al., 2007). The current land surface representation in ModelE (Abramopoulos et al., 1988; Rosenzweig and Abramopoulos, 1997; Aleinov and Schmidt, 2006) can include separate bare soil, vegetated soil, and lake fractions within each grid cell. Soil moisture, soil temperature, and land-atmosphere fluxes are computed for the two separate soil columns whenever bare soil and vegetated areas coexist within a grid cell. Vegetation and phenology are based on Matthews (1983) and Matthews (1984), while photosynthesis and stomatal conductance are computed using the functions of Farquhar et al. (1980) and Ball et al. (1987). Each soil column is discretized into six soil layers with a total depth of $3.5 \mathrm{~m}$, with runoff from each layer depending on its water content and soil properties. In the current configuration, there are no heat or water fluxes across the bottom of the soil column.

Soil properties are derived from the data sets described in Rosenzweig and Abramopoulos (1997), except that bedrock fractions in the deepest soil layers (layers 5 and 6) were reduced to the layer 4 fraction. Vegetation characteristics (leaf area index, maximum vegetation height, and root density and depth) are also as specified in Rosenzweig and Abramopoulos (1997), except for changes to root density and depth. The roots of woodland, deciduous tree, and evergreen tree vegetation types are redistributed, so that $20 \%$ of the roots are in the bottom two layers (below $1 \mathrm{~m}$ ). These modifications to bedrock function and root depth allow vegetation greater access to deeper soil moisture, and permit more extensive interaction between the soil and the aquifer layer. Multiple studies have identified access to deeper soil moisture as an important aspect of water uptake by plants during dry periods; deep roots have been found to take up substantial amounts of water from deep, wet soil when shallow layers dry out, even if their contribution to root biomass is small (Jackson et al., 2000; Feddes et al., 2001; Lee et al., 2005; El Maayar et al., 2009).

\subsection{Aquifer representation}

We developed a simple, computationally efficient, water- and energy-conserving implementation of water and heat flow vertically between the soil column and an unconfined aquifer. The aquifer is represented as a single additional layer underlying the bottom soil layer.

The state variables added were the aquifer water content $w_{\text {aq }}$ (volume of liquid water equivalent per unit area, $\mathrm{m}$ ) and heat content $h_{\text {aq }}$ (energy per unit area, $\mathrm{J} \mathrm{m}^{-2}$ ). We assumed hydraulic and thermal equilibrium within the aquifer layer 
(i.e., uniform water potential and temperature). The proportionality factor between change in aquifer water content and change in the equilibrium water table is the specific yield $S_{y}$ :

$\Delta z_{\Delta}=\frac{\Delta w_{\mathrm{aq}}}{S_{y}}$.

In reality, $S_{y}$ depends on the water table depth $z_{\Delta}$ as well as on the profile of the specific moisture capacity above the water table. We simplified it by assuming a constant $S_{y}=$ 0.2 , which Niu et al. (2007) found to give reasonable results globally. With constant $S_{y}$, we can write

$z_{\Delta}=z_{\text {lower }}+\frac{w_{\mathrm{aq}}}{S_{y}}$,

where $z_{\text {lower }}$ is the bottom depth of the aquifer, taken to be $-53.5 \mathrm{~m}$. A full aquifer corresponds to $z_{\Delta}$ equaling the depth of the bottom soil layer, $-3.5 \mathrm{~m}$.

The aquifer heat content $h_{\mathrm{aq}}$ is equal to the aquifer water's specific enthalpy $H_{\mathrm{aq}}$ times its density $\rho$ times its volume $w_{\text {aq }}$, plus the corresponding values for the bedrock (assumed to occupy $1-S_{y}$ of the aquifer volume and to have a specific heat capacity $H \rho$ of $2.4 \times 10^{6} \mathrm{~J} \mathrm{~m}^{-3} \mathrm{~K}^{-1}$ ). The heat content yields a corresponding aquifer temperature $T_{\mathrm{aq}}$ (cf. Rosenzweig and Abramopoulos, 1997, Eq. 2).

We assume that at the bottom of the modeled soil layers, the water potential (in units of $m$ ) is at its value for the aquifer, which is $z_{\Delta}$. At the midpoint of the bottom model soil layer (layer 6), which has total thickness $\Delta z_{N}=1.53 \mathrm{~m}$ and (vertical) hydraulic conductivity $K_{N}$, the water potential is equal to the model-calculated value for the bottom layer, $h_{N}$. A finite-difference approximation to Darcy's law gives for the water flux $q$ between the soil and aquifer (volume of liquid water per unit area per unit time):

$q_{\text {soil-aquifer }}=K_{N} \frac{2\left(h_{N}-z_{\Delta}\right)}{\Delta z_{N}}$.

Thus there is no vertical water flow in or out the aquifer if $z_{\Delta}=h_{N}$, while there can be flow from the aquifer into the soil if $z_{\Delta}>h_{N}$.

Note that unlike in SIMGM, there is no runoff directly from the aquifer. ModelE has subsurface runoff originating from the soil layers depending on their water content (Abramopoulos et al., 1988). Total runoff remains roughly constant after adding the aquifer layer.

Heat flux $q_{\mathrm{H}}$ between the aquifer and soil $\left(\mathrm{W} \mathrm{m}^{-2}\right)$ is given by

$q_{\mathrm{H} ; \text { soil-aquifer }}=K_{\mathrm{H} ; N} \frac{2\left(T_{N}-T_{\mathrm{aq}}\right)}{\Delta z_{N}}+q_{\text {soil-aquifer }} C_{p} T$,

where $K_{\mathrm{H} ; N}$ is the bottom soil layer's (vertical) thermal conductivity ( $\left.\mathrm{W} \mathrm{m}^{-1} \mathrm{~K}^{-1}\right), T_{N}$ is the temperature of the bottom soil layer, and in the second term the water specific heat $C_{p}$ and the temperature $T$ are evaluated on the upstream side (cf. Rosenzweig and Abramopoulos, 1997, Eq. 1).

Water and heat flows given by these expressions for each timestep are restricted to ensure numerical stability (specifically, the aquifer water content is not allowed to decline by more than half at each timestep) and to prevent the aquifer from overfilling (maximum aquifer water content, given the parameter values we chose, is $10 \mathrm{~m}$ ) or emptying (minimum water content set at $10^{-6} \mathrm{~m}$ ). Also, the hydraulic conductivity is reduced to zero if the water on the upstream side is frozen.

As previously in ModelE and in other climate models (Nicolsky et al., 2007), geothermal heat flow is neglected in assuming no-flux bottom boundary conditions. Adding geothermal heat flow would be expected to warm our aquifer layer by up to about $1 \mathrm{~K}$, taking a typical continental geotherm of $25 \mathrm{~K} \mathrm{~km}^{-1}$ (Mock et al., 1997). This heat flow may be more important over multi-millennium simulations, particularly for representing conditions at the bottom of ice sheets (Pollard et al., 2005).

\subsection{Model runs and analysis}

Two ModelE runs were conducted starting from the same initial conditions, one (Control) without an aquifer and with the usual no-flux boundary condition at the bottom of the soil layers and the other (Aquifer) with an aquifer layer as described. Both runs included dynamic atmosphere and land surface processes. All climate forcings were set to 1850 conditions, and climatological sea surface temperatures and sea ice were specified based on 1876-1885 average conditions from the HadISST 1.1 data set (Rayner et al., 2003). For the Aquifer run, the aquifer was initialized with heat and water contents that corresponded to the monthly mean temperature and water potential of the bottom soil layer taken from the end of a previous run.

Two additional ModelE runs, WaterOnly and HeatOnly, were carried out in order to evaluate whether particular differences found between the Control and Aquifer runs could be attributed primarily to the heat flux or to the water flux between the aquifer and the soil column. Both these runs started from the same initial condition as the Aquifer run and used the same model formulation, except as follows. In WaterOnly, the thermal conductivity in Eq. (4) was set to zero; therefore, there was no heat transfer between the aquifer and the soil column (except for heat carried by water fluxes). In HeatOnly, the hydraulic conductivity in Eq. (3) was set to zero; thus there was no transfer of water between the aquifer and the soil column, and the aquifer water content stayed fixed at its initial value.

The Aquifer, HeatOnly, and WaterOnly runs were each run to approximate equilibrium. In the Aquifer and WaterOnly runs, trends in the aquifer water content were extrapolated several times by fitting exponential decay functions to the time series and then re-initializing runs with the extrapolated 

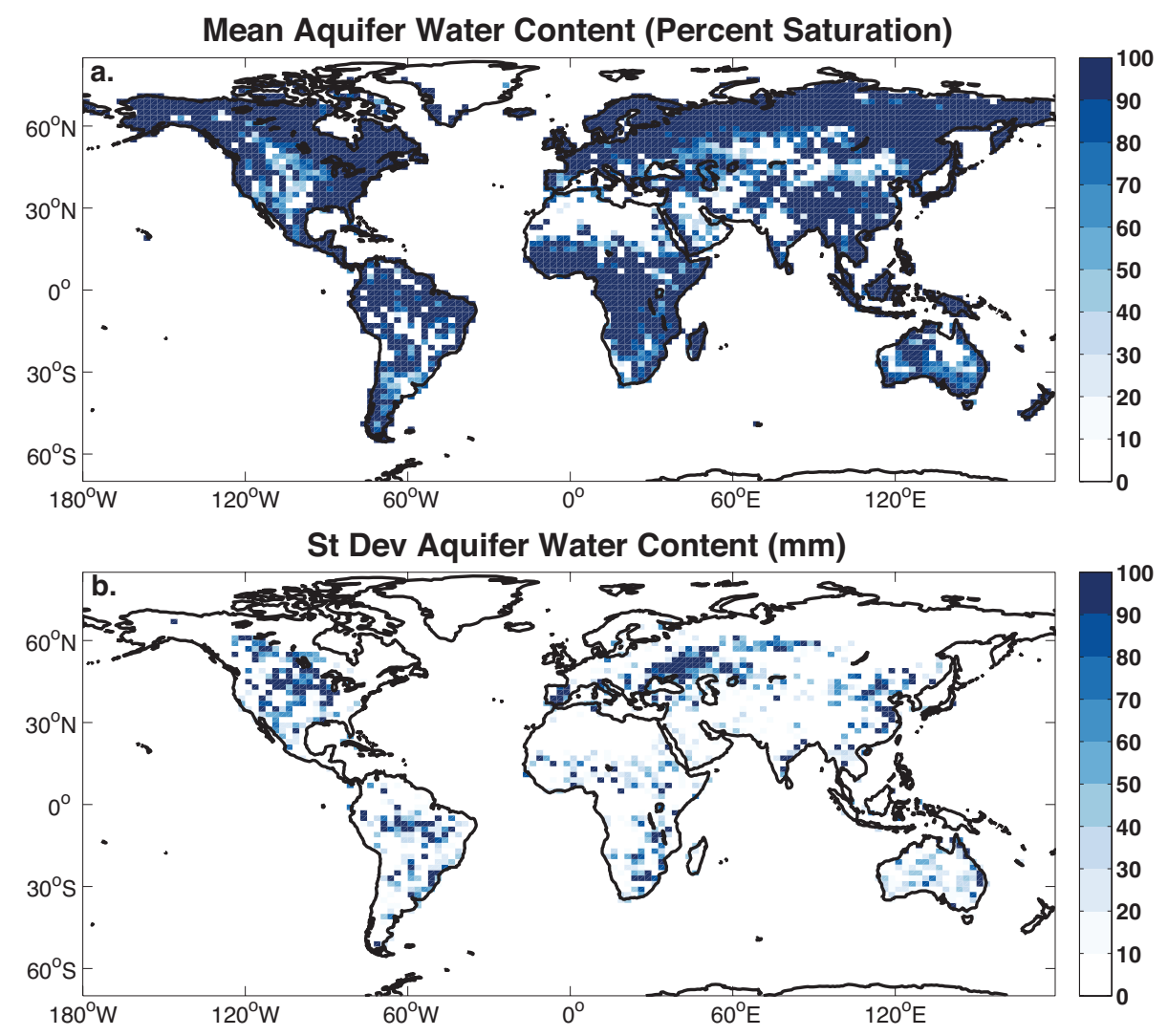

Fig. 1. (a) Mean aquifer water content (expressed as fraction of capacity) in the Aquifer run. (b) Standard deviation (mm) of monthly mean aquifer water content in the Aquifer run.

water contents in an attempt to speed up convergence. Time series of hemispheric and global means in model outputs including surface temperature, precipitation, evaporation, soil temperature and moisture, and aquifer temperature and water content were inspected to verify that all runs were in approximate steady state. All results shown here are based on the last $50 \mathrm{yr}$ from each simulation.

In the Aquifer and WaterOnly runs, the equilibrium aquifer water content was primarily controlled by climate, with a full aquifer in moist areas such as the Congo basin and western Europe and an empty aquifer in deserts (Fig. 1a). As might be expected, under both these extreme conditions the aquifer water content showed little time variability, while the greatest variability (indicative of significant aquifer-soil water fluxes) was seen in areas of intermediate dryness such as the central United States, the Eurasian steppes, and northeastern China, where the aquifer water content was intermediate and fluctuating (Fig. 1b).

Soil temperature is shown (in the Tables and in Fig. 3) averaged across the soil column (to $3.5 \mathrm{~m}$ depth), and soil water content is similarly summed across the soil layers. The significance of differences between Control and the other runs (Aquifer, WaterOnly, HeatOnly) was estimated using Student's $t$ test on time series of the difference between two runs taken at annual resolution, with the degrees of freedom adjusted based on the observed lag-1 autocorrelation of the time series. Global mean interannual standard deviation of a climate variable was defined as the average of the interannual standard deviation across grid cells, and global mean lagged autocorrelation was defined as the autocorrelation of monthly-mean climate variables at a specified lag ( 3,12 , or 48 months), averaged across grid cells. For the interannual standard deviations and autocorrelations, standard errors of differences in the global mean between runs was calculated using their variances and covariances on the grid scale as estimated by fitting a spatial Gaussian random process with exponential variogram (Cressie, 1993) to the map of differences.

\section{Results}

\subsection{Aquifer impact on mean climate and seasonal cycles}

As Table 1 shows, soil-aquifer fluxes had remarkably little effect on the mean of climate variables in ModelE. Soil moisture increased when soil-aquifer water fluxes were included, because the aquifer provided a storage for excess water when the soil is saturated that can be released as the soil 

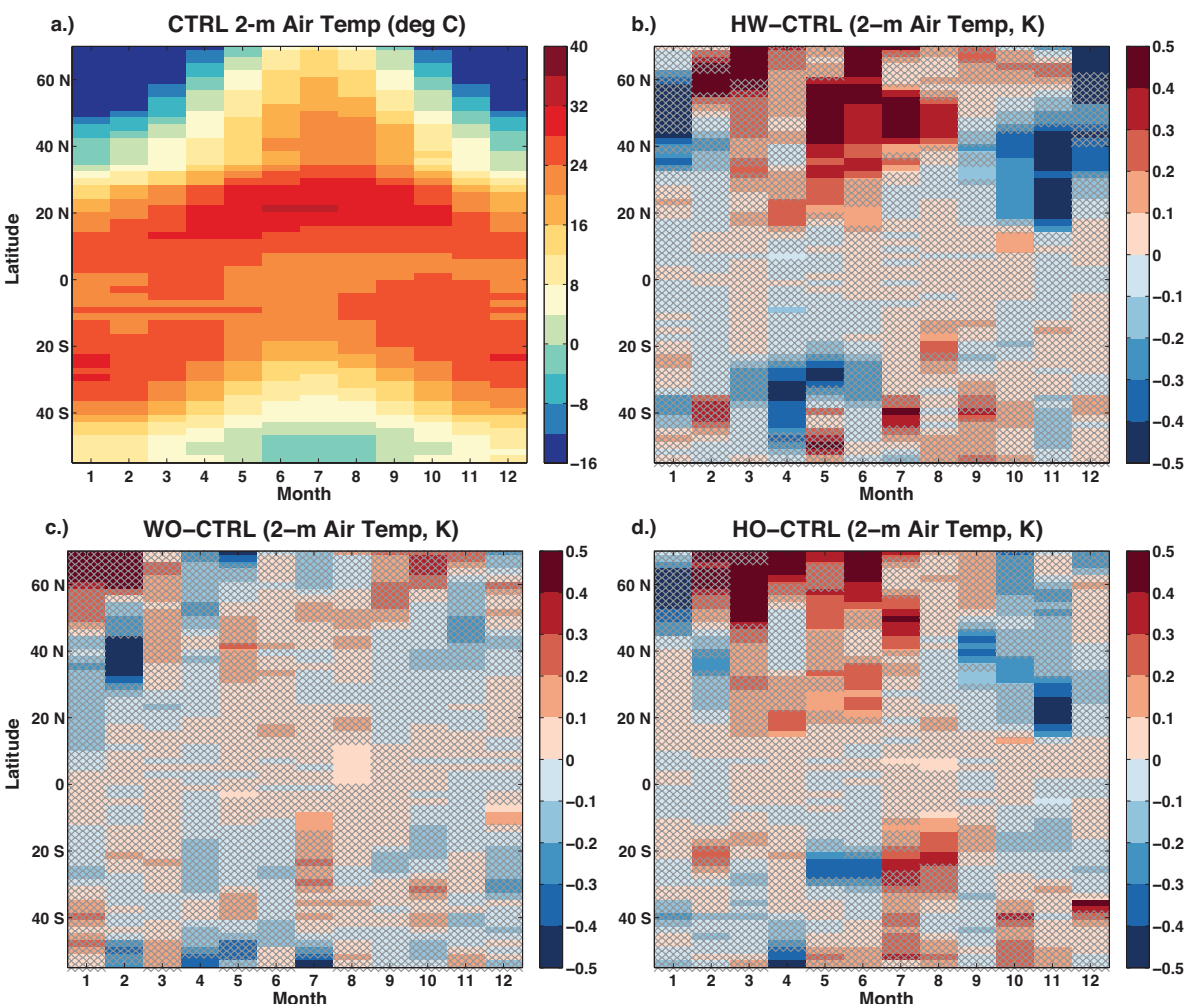

Fig. 2. Month-latitude climatologies of surface air temperature. (a) Control run. (b) Aquifer minus Control run. (c) WaterOnly minus Control run. (d) HeatOnly minus Control run. For (b-d), differences not significant at the 0.05 level are hatched.
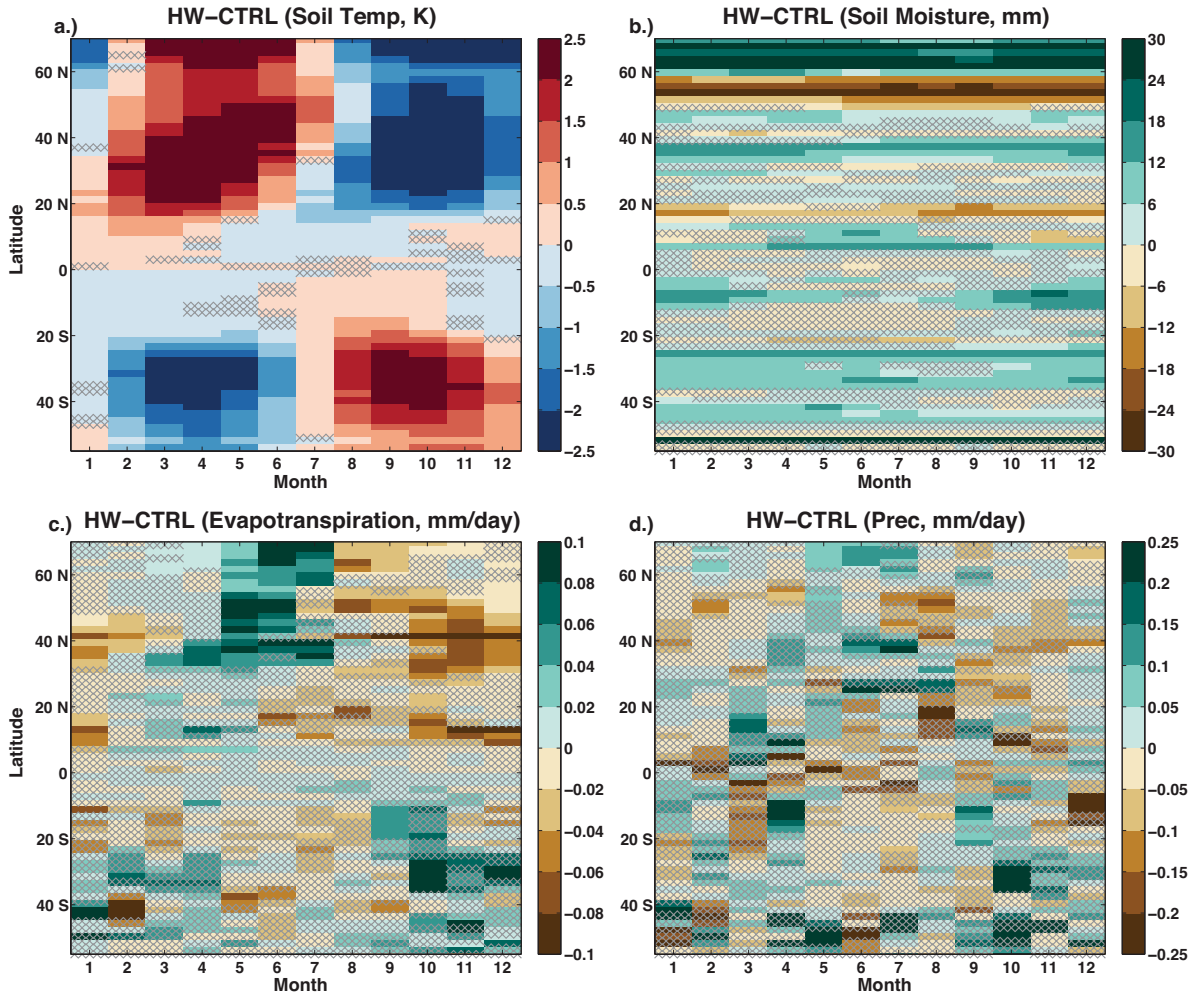

Fig. 3. Month-latitude climatologies, Aquifer minus Control run. (a) Soil temperature. (b) Soil moisture. (c) Evaporation. (d) Precipitation. Differences not significant at the 0.05 level are hatched. 
Table 1. Mean of climate variables

\begin{tabular}{lcccc}
\hline & Control & Aquifer & WaterOnly & HeatOnly \\
\hline Soil temperature $\left({ }^{\circ} \mathrm{C}\right)$ & 14.30 & 14.29 & 14.30 & 14.30 \\
Soil water $(\mathrm{mm})$ & 687.4 & $690.6^{* *}$ & $690.5^{*}$ & 689.1 \\
Surface air temperature $\left({ }^{\circ} \mathrm{C}\right)$ & 14.12 & 14.15 & 14.13 & $14.16^{* *}$ \\
Evaporation $\left(\mathrm{mm} \mathrm{day}^{-1}\right)$ & 1.996 & 1.996 & 1.995 & 1.996 \\
Precipitation $\left(\mathrm{mm} \mathrm{day}^{-1}\right)$ & 2.982 & 2.979 & 2.979 & 2.986 \\
\hline
\end{tabular}

Averaged over land grid cells (excluding ice caps). Significance level of differences between Control and other runs: $* 0.05, * * 0.01$.

Table 2. Interannual standard deviation of climate variables.

\begin{tabular}{lcccc}
\hline & Control & Aquifer & WaterOnly & HeatOnly \\
\hline Soil temperature $\left({ }^{\circ} \mathrm{C}\right)$ & 0.49 & $0.24 * *$ & $0.47^{*}$ & $0.24^{* *}$ \\
Soil water $(\mathrm{mm})$ & 32.5 & $26.8^{* *}$ & $27.3^{* *}$ & $31.7^{*}$ \\
Surface air temperature $\left({ }^{\circ} \mathrm{C}\right)$ & 0.56 & $0.52^{*}$ & $0.52^{*}$ & $0.52^{*}$ \\
Evaporation $\left(\mathrm{mm} \mathrm{day}^{-1}\right)$ & 0.134 & 0.132 & 0.130 & 0.132 \\
Precipitation $\left(\mathrm{mm} \mathrm{day}^{-1}\right)$ & 0.365 & 0.363 & 0.358 & 0.363 \\
\hline
\end{tabular}

Averaged over land grid cells (excluding ice caps). Significance level of differences between Control and other runs: $* 0.05, * * 0.01$.

dries, but this increase was quantitatively tiny (less than $1 \%$ ) and did not lead to significant change in evaporation or surface air temperature. Surface air temperature increased when soil-aquifer heat fluxes were included, perhaps due to the interaction of seasonal heat fluxes (see below) with the snow thermal rectifier (Goodrich, 1982) at high latitudes, but this increase is again tiny (less than $0.1 \mathrm{~K}$ ).

Considering changes by season as well as latitude band tells a more interesting story. The soil-aquifer heat flux greatly dampens the amplitude of the seasonal cycle in temperature in the deeper soil layers, which lags the seasonal cycle in surface insolation by some 2-3 months. This heat flux propagates to the surface with additional phase lag, with the result that the surface warms in February-August (by up to $\sim 0.7 \mathrm{~K}$ at high latitudes) and cools in September-January (by similar amounts) in the Aquifer and HeatOnly simulations, actually increasing the seasonal amplitude of temperature at the surface (Fig. 2). The change in soil temperature is greater than in surface air temperature, with warming/cooling zonally exceeding $2 \mathrm{~K}$ (Fig. 3a).

Soil moisture considered by latitude shows significant, though modest, changes (typically 1-3\%) (Fig. 3b). Notably, soil moisture decreases around $50^{\circ} \mathrm{N}$, possibly because of greater evaporation (Fig. 3c) during warmer springs and summers (Fig. 2b). Soil moisture increases further north, as increasing warm-season evaporation there is more than balanced by increasing summer precipitation (Fig. 3d) associated with warmer conditions.

The reduced amplitude of the soil temperature seasonal cycle means that more grid cells are modeled to have permafrost, which we operationally define as the bottom model soil layer (layer 6, 1.97-3.50 m depth) never warming above freezing during a run. The permafrost area almost doubles from 9.1 million to 16.1 million $\mathrm{km}^{2}$, in better agreement with observation-based inventories which yield a range of 12.2-17.0 million $\mathrm{km}^{2}$ (Zhang et al., 2000). Permafrost expands south and east in Siberia, across the Tibetan plateau, and around the Arctic coast in North America (Fig. 4; compare with the observation-based permafrost map at http://www.grida.no/graphicslib/detail/ permafrost-extent-in-the-northern-hemisphere_1266).

Given the importance of permafrost for sequestering carbon, this change might be expected to have significant impacts on modeled biogeochemistry and response to global warming (Koven et al., 2011).

\subsection{Aquifer impact on climate variability and persistence}

Table 2 shows the change between runs of the mean interannual variability in the climate variables previously considered. Soil temperature and moisture are both stabilized by adding the aquifer layer. As expected, soil temperature responds more to the soil-aquifer heat flux, while soil moisture responds more to the water flux, but both fluxes have some effect on the variability in both quantities. Surface air temperature variability is also reduced, again showing that the influence of aquifer-soil fluxes is detectable in the atmosphere, but evaporation and precipitation do not show significant change.

Table 3 shows the change between runs in the lagged autocorrelation of climate variables at timescales of 3,12 , and 48 months, a measure of the climate system's memory at seasonal to interannual timescales. Soil temperature shows 


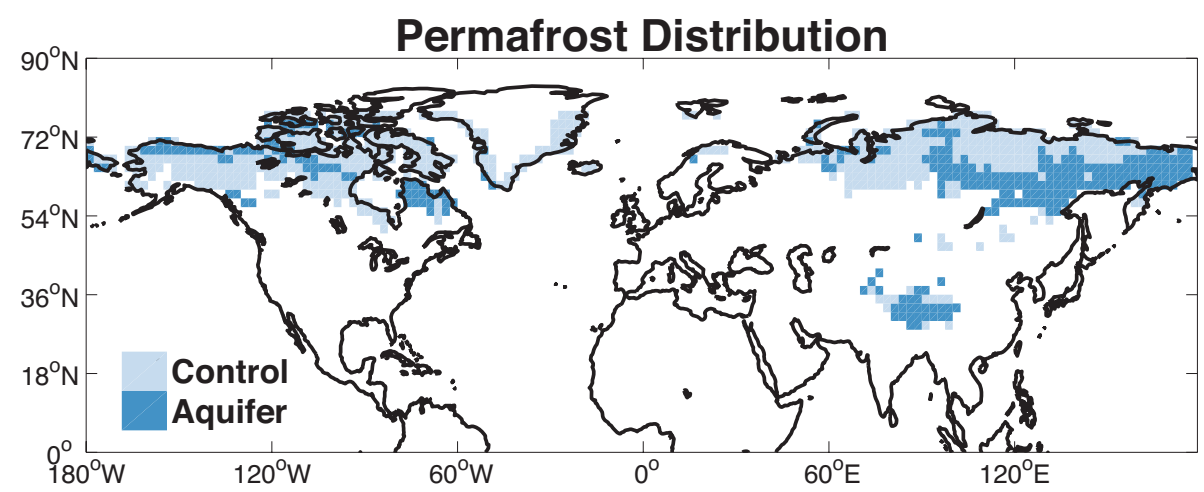

Fig. 4. Permafrost extent in the Control run (light blue) and additional permafrost area in the Aquifer run (dark blue).

much reduced autocorrelation due to soil-aquifer fluxes (primarily the heat flux) at 3-month lag, while at 1-year lag there is little autocorrelation and no significant difference between runs. Soil moisture shows stronger autocorrelation, which is decreased especially by the soil-aquifer water flux; the aquifer acts as a reservoir with much longer timescale than $1 \mathrm{yr}$, and thus dampens the land-surface memory at annual and shorter timescales. This loss of memory is also reflected, to a lesser but still significant extent, in decreased autocorrelations of surface air temperature (at 3-month lag) and evaporation (at a lag of $1 \mathrm{yr}$ ). At a $4 \mathrm{yr}$ lag, all autocorrelations are close to zero and few of the differences between runs are significant.

\section{Discussion}

We have used an idealized model of soil-aquifer heat and water fluxes to assess the likely impact of those fluxes on different aspects of global climate. To what extent might our conclusions change as our aquifer model becomes more complex and realistic?

For heat flux, it is easy to calculate the effect of aquifer depth and vertical discretization, assuming that thermal conductivity is approximately constant with depth. A one-layer aquifer will somewhat overstate seasonal soil-aquifer heat fluxes compared to a model with finer vertical discretization (Alexeev et al., 2007), so that the effect we find on climate of the soil-aquifer heat flux can be regarded as an upper limit of what we would see as we make our subsurface model more realistic.

Similarly, assuming a uniform water potential within the aquifer layer (equivalent to infinite hydraulic conductivity within the layer), as we did here, will tend to lead to water fluxes that are higher than would be expected in reality for the same mean water contents in the aquifer and soil layers. Thus the effect we find on climate of the soil-aquifer water flux can also be regarded as an upper limit.

Beyond such discretization effects, which could be mitigated by dividing the aquifer into several thinner layers, developing realistic models of subsurface water fluxes is complicated by the wide variation in subsurface hydraulic properties, which makes it difficult to develop a model that gives the right flux magnitudes on the grid scale used in GCMs (Choi et al., 2007). Three-dimensional subsurface variability in specific yields and hydraulic conductivity, mentioned by Miguez-Macho et al. (2008) as a key source of uncertainty in modeling water tables at high horizontal resolution, requires subsurface property data sets usable for largescale modeling, similar to those available for surface soil properties. An initial step has been taken by Gleeson et al. (2011), who compiled representative values for the permeability of various lithologies based on watershed-scale hydrologic studies. Available water table and streamflow data along with total water storage changes from the GRACE satellites may also be useful for calibration of parameters in GCM simple aquifer representations, using one of several already demonstrated approaches (Lo et al., 2010; Werth and Güntner, 2010; Becker et al., 2011; Vergnes and Decharme, 2012), particularly when the GCM runs include more realistic climate variability (compared to the climatological sea surface temperatures and greenhouse gas concentrations used in the runs reported here, which were intended to represent an idealized, stable preindustrial climate). Soil data obtained at different depths, now being aggregated in the International Global Soil Moisture Network (ISMN, which holds soil temperature as well as water content data) (Dorigo et al., 2011), may also be useful in validating the modeled effects of water and heat fluxes on the soil temperature and moisture profiles and on their temporal correlation patterns, though meaningfully comparing global model outputs to in situ measurements of soil properties remains a challenge (Seneviratne et al., 2010; Luo et al., 2012). Borehole temperature measurements may also be useful in validating model heat fluxes over depths up to hundreds of meters under conditions of climate change (Beltrami et al., 2006).

For water flux, horizontal as well as vertical flow within the subsurface is likely to be important at least in setting equilibrium water distributions, such as relatively high water 
Table 3. Autocorrelation of climate variables at 3, 12, and 48 month lags.

\begin{tabular}{|c|c|c|c|c|}
\hline & Control & Aquifer & WaterOnly & HeatOnly \\
\hline \multicolumn{5}{|l|}{3 month lag: } \\
\hline Soil temperature $\left({ }^{\circ} \mathrm{C}\right)$ & 0.449 & $0.151 * *$ & $0.428^{*}$ & $0.145 * *$ \\
\hline Soil water $(\mathrm{mm})$ & 0.595 & $0.578 *$ & $0.574 *$ & 0.592 \\
\hline Surface air temperature $\left({ }^{\circ} \mathrm{C}\right)$ & 0.055 & $0.036^{*}$ & $0.035^{*}$ & $0.030 *$ \\
\hline Evaporation $\left(\mathrm{mm} \mathrm{day}^{-1}\right)$ & 0.081 & 0.077 & 0.075 & $0.075^{*}$ \\
\hline Precipitation $\left(\mathrm{mm} \mathrm{day}^{-1}\right)$ & 0.010 & 0.005 & $0.003^{*}$ & 0.004 \\
\hline \multicolumn{5}{|l|}{12 month lag: } \\
\hline Soil temperature $\left({ }^{\circ} \mathrm{C}\right)$ & 0.053 & 0.029 & 0.042 & 0.045 \\
\hline Soil water $(\mathrm{mm})$ & 0.272 & $0.229 * *$ & $0.235 * *$ & $0.258 *$ \\
\hline Surface air temperature $\left({ }^{\circ} \mathrm{C}\right)$ & -0.003 & -0.018 & -0.014 & -0.004 \\
\hline Evaporation $\left(\mathrm{mm} \mathrm{day}^{-1}\right)$ & 0.010 & $0.000 * *$ & $-0.001 * *$ & $0.002 *$ \\
\hline Precipitation $\left(\mathrm{mm} \mathrm{day}^{-1}\right)$ & -0.016 & -0.021 & -0.019 & -0.014 \\
\hline \multicolumn{5}{|l|}{48 month lag: } \\
\hline Soil temperature $\left({ }^{\circ} \mathrm{C}\right)$ & -0.011 & 0.007 & -0.024 & 0.015 \\
\hline Soil water $(\mathrm{mm})$ & 0.071 & 0.055 & $0.048 * *$ & 0.068 \\
\hline Surface air temperature $\left({ }^{\circ} \mathrm{C}\right)$ & -0.026 & -0.012 & -0.018 & -0.011 \\
\hline Evaporation $\left(\mathrm{mm} \mathrm{day}^{-1}\right)$ & -0.017 & -0.019 & -0.013 & $-0.009 *$ \\
\hline Precipitation $\left(\mathrm{mm}\right.$ day $\left.^{-1}\right)$ & -0.021 & -0.022 & -0.019 & -0.015 \\
\hline
\end{tabular}

Averaged over land grid cells (excluding ice caps). Significance level of differences between Control and other runs: $* 0.05, * * 0.01$.

tables in valleys, and also for sustaining baseflow in rivers (Tóth, 1963; Fan et al., 2007). Horizontal subsurface flow may also be important as a driver of long-timescale hydroclimate persistence (Bierkens and van den Hurk, 2007). Again, representing this at the GCM grid scale is an unsolved problem, and will probably require estimating effective horizontal hydraulic conductivities and rates of subsurface runoff from groundwater simulations run and validated at much higher resolution (Fan et al., 2007, 2013; Lam et al., 2011; Sutanudjaja et al., 2011).

Another way in which our model could be refined is to include a fraction of deep roots that reach below the $3.5 \mathrm{~m}$ deep soil column (Stone and Kalisz, 1991), whether in permeable deep soil or regolith (Nepstad et al., 1994; Markewitz et al., 2010) or even in fractured bedrock (Schwinning, 2010; Roering et al., 2010). This direct connection of transpiring vegetation to "aquifer" layers would likely increase their impact on water budget variables such as evaporation (Fan and Miguez-Macho, 2010).

Our results show that soil-aquifer interactions affect the seasonality and persistence of climate variables as well as, to a small extent, their mean (e.g., soil moisture increases by $0.5 \%$ ). However, the impacts that we find of aquifer interactions on mean climate are much smaller than those shown by Lo and Famiglietti (2011) for CLM, where, for example, including the aquifer component led to increases of $9 \%$ in global mean land evaporation and 3\% in global land precipitation, while we see changes of much less than $1 \%$ in both these variables. Plausibly, this is because adding the aquifer parametrization to CLM dispensed with the prior free-drainage bottom boundary condition for soil moisture, which had led to chronically dry soils (Zeng and Decker, 2009). ModelE, by contrast, has a no-flow bottom boundary condition in the Control configuration, which leads to the same result (no water flux at the soil lower boundary) as an aquifer at hydraulic equilibrium with the deep soil. Thus adding the aquifer modified the variability of soil temperature and moisture in ModelE but had much less impact on the mean climate state than in CLM. Based on our results, we hypothesize that modifying a land surface model with a no-flux bottom boundary condition to include soilaquifer heat and water fluxes that are physically consistent and of realistic magnitude will in general lead to very limited change in mean temperatures and hydrological budgets, although the changes in seasonal and interannual variability might be quite significant from, for example, a biogeochemical standpoint (as for permafrost extent).

By controlling heat and water fluxes separately, we found that both can impact variability in such quantities as soil moisture and evaporation. Along similar lines, soil moisture changes can significantly influence soil temperature profiles and permafrost extent by changing the effective thermal conductivity (Subin et al., 2013). These results underline the desirability of simulating soil-aquifer heat and water fluxes together in a physically consistent way, since one or the other 
in isolation will not fully represent the impact of the deep subsurface on climate variability and persistence.

We found that soil-aquifer fluxes tend to decrease the autocorrelation of land-surface and climate variables (soil temperature and moisture, surface air temperature, evaporation, and precipitation) on timescales of up to $1 \mathrm{yr}$. On longer timescales, it is plausible that aquifers contribute to multiyear climate memory and persistence (e.g., long droughts and pluvials), although we did not find conclusive evidence for this in the analyses presented here. One caveat for interpreting our model results is that our runs had artificially low interannual variability in climate forcing and sea-surface boundary conditions (SSTs kept at climatology, constant greenhouse gas levels); a next step will be to examine how climate persistence changes in the presence of more variability, as well as in the presence of changing climate forcings such as greenhouse gas levels. As another example of long-term change, drawdown of groundwater for irrigation, now observable in many parts of the world (Tiwari et al., 2009; Kustu et al., 2010; Famiglietti et al., 2011), may contribute to regional drying, although the added irrigation results in moister soil, higher evaporation, surface cooling, and higher precipitation over the short term (Sacks et al., 2009; Cook et al., 2011; Ferguson and Maxwell, 2012).

\section{Conclusions}

We present and test an idealized parametrization of water and heat flow between a subsoil aquifer and the soil column in the GISS ModelE GCM. The simple aquifer parametrization used here suffices to show the impact of these fluxes on seasonality and the potential impact of groundwater on persistence of soil moisture and climate. Many aspects of this parametrization (e.g., single aquifer layer, no flow between grid cells, no roots below the soil column) can usefully be refined to study these impacts with more detail and accuracy, especially as they relate to temperature and moisture changes resulting from anthropogenic climate change and aquifer depletion.

Acknowledgement. This study was supported by the National Oceanic and Atmospheric Administration (NOAA) under Grants NA06OAR4810162, NA11SEC4810004 and NA12OAR4310084. The statements contained in this article are not the opinions of the funding agency or government, but reflect the views of the authors.

Edited by: S. Seneviratne

\section{References}

Abramopoulos, F., Rosenzweig, C., and Choudhury, B.: Improved ground hydrology calculations for global climate models (GCMs): soil water movement and evapo- transpiration, J. Climate, 1, 921-941, doi:10.1175/15200442(1988)001<0921:IGHCFG > 2.0.CO;2, 1988.

Aleinov, I. and Schmidt, G.: Water isotopes in the GISS ModelE land surface scheme, Global Planet. Change, 51, 108-120, doi:10.1016/j.gloplacha.2005.12.010, 2006.

Alexeev, V. A., Nicolsky, D. J., Romanovsky, V. E., and Lawrence, D. M.: An evaluation of deep soil configurations in the CLM3 for improved representation of permafrost, Geophys. Res. Lett., 34, L09502, doi:10.1029/2007GL029536, 2007.

Anyah, R. O., Weaver, C. P., Miguez-Macho, G., Fan, Y., and Robock, A.: Incorporating water table dynamics in climate modeling: 3. Simulated groundwater influence on coupled land-atmosphere variability, J. Geophys. Res., 113, D07103, doi:10.1029/2007JD009087, 2008.

Ball, J. T., Woodrow, I. E., Berry, J. A., and Biggins, I.: A model predicting stomatal conductance and its application to the control of photosynthesis under different environmental conditions, in: Progress in Photosynthesis, 221-224, Martinus Nijhoff Publishers, Zoetermeer, Netherlands, 1987.

Becker, M., Meyssignac, B., Xavier, L., Cazenave, A., Alkama, R., and Decharme, B.: Past terrestrial water storage (19802008) in the Amazon Basin reconstructed from GRACE and in situ river gauging data, Hydrol. Earth Syst. Sci., 15, 533-546, doi:10.5194/hess-15-533-2011, 2011.

Beltrami, H., Bourlon, E., Kellman, L., and Gonzalez-Rouco, J. F. Spatial patterns of ground heat gain in the Northern Hemisphere, Geophys. Res. Lett., 33, L06717, doi:10.1029/2006GL025676, 2006.

Bierkens, M. F. P. and van den Hurk, B. J. J. M.: Groundwater convergence as a possible mechanism for multi-year persistence in rainfall, Geophys. Res. Lett., 34, L02402, doi:10.1029/2006GL028396, 2007.

Bonan, G. B. and Levis, S.: Evaluating aspects of the community land and atmosphere models (CLM3 and CAM3) using a dynamic global vegetation model, J. Climate, 19, 2290-2301, 2006.

Choi, H. I. and Liang, X.-Z.: Improved terrestrial hydrologic representation in mesoscale land surface models, J. Hydrometeorol., 11, 797-809, doi:10.1175/2010JHM1221.1, 2010.

Choi, H. I., Kumar, P., and Liang, X.-Z.: Three-dimensional volume-averaged soil moisture transport model with a scalable parameterization of subgrid topographic variability, Water Resour. Res., 43, W04414, doi:10.1029/2006WR005134, 2007.

Cook, B. I., Puma, M. J., and Krakauer, N. Y.: Irrigation induced surface cooling in the context of modern and increased greenhouse gas forcing, Clim. Dynam., 37, 1587-1600, doi:10.1007/s00382-010-0932-x, 2011.

Cressie, N. A.: Statistics for Spatial Data, Wiley, New York, revised Edn., 1993.

Dickinson, R. E., Oleson, K. W., Bonan, G., Hoffman, F., Thornton, P., Vertenstein, M., Yang, Z.-L., and Zeng, X.: The Community Land Model and its climate statistics as a component of the Community Climate System Model, J. Climate, 19, 2302-2324, doi:10.1175/JCLI3742.1, 2006.

Dorigo, W. A., Wagner, W., Hohensinn, R., Hahn, S., Paulik, C., Xaver, A., Gruber, A., Drusch, M., Mecklenburg, S., van Oevelen, P., Robock, A., and Jackson, T.: The International Soil Moisture Network: a data hosting facility for global in situ soil moisture measurements, Hydrol. Earth Syst. Sci., 15, 1675-1698, doi:10.5194/hess-15-1675-2011, 2011. 
El Maayar, M., Price, D. T., and Chen, J. M.: Simulating daily, monthly and annual water balances in a land surface model using alternative root water uptake schemes, Adv. Water Resour., 32, 1444-1459, doi:10.1016/j.advwatres.2009.07.002, 2009.

Essery, R. L. H., Best, M. J., Betts, R. A., Cox, P. M., and Taylor, C. M.: Explicit representation of subgrid heterogeneity in a GCM land surface scheme, J. Hydrometeorol., 4, 530-543, 2003.

Famiglietti, J. S., Lo, M., Ho, S. L., Bethune, J., Anderson, K. J., Syed, T. H., Swenson, S. C., de Linage, C. R., and Rodell, M.: Satellites measure recent rates of groundwater depletion in California's Central Valley, Geophys. Res. Lett., 38, L03403, doi:10.1029/2010GL046442, 2011.

Fan, Y. and Miguez-Macho, G.: Potential groundwater contribution to Amazon evapotranspiration, Hydrol. Earth Syst. Sci., 14, 2039-2056, doi:10.5194/hess-14-2039-2010, 2010.

Fan, Y., Miguez-Macho, G., Weaver, C. P., Walko, R., and Robock, A.: Incorporating water table dynamics in climate modeling: 1. Water table observations and equilibrium water table simulations, J. Geophys. Res., 112, D10125, doi:10.1029/2006JD008111, 2007.

Fan, Y., Li, H., and Miguez-Macho, G.: Global patterns of groundwater table depth, Science, 339, 940-943, doi:10.1126/science.1229881, 2013.

Farquhar, G. D., von Caemmerer, S., and Berry, J. A.: A biochemical model of photosynthetic $\mathrm{CO}_{2}$ assimilation in leaves of $\mathrm{C}_{3}$ species, Planta, 149, 78-90, 1980.

Feddes, R. A., Hoff, H., Bruen, M., Dawson, T., de Rosnay, P., Dirmeyer, P., Jackson, R. B., Kabat, P., Kleidon, A., Lilly, A., and Pitman, A. J.: Modeling root water uptake in hydrological and climate models, B. Am. Meteorol. Soc., 82, 2797-2810, doi:10.1175/1520-0477(2001)082<2797:MRWUIH > 2.3.CO;2, 2001.

Ferguson, I. M. and Maxwell, R. M.: Human impacts on terrestrial hydrology: climate change versus pumping and irrigation, Environ. Res. Lett., 7, 044022, doi:10.1088/1748-9326/7/4/044022, 2012.

Gleeson, T., Smith, L., Moosdorf, N., Hartmann, J., Dürr, H. H., Manning, A. H., van Beek, L. P. H., and Jellinek, A. M.: Mapping permeability over the surface of the Earth, Geophys. Res. Lett., 38, L02401, doi:10.1029/2010GL045565, 2011.

Goodrich, L. E.: The influence of snow cover on the ground thermal regime, Can. Geotech. J., 19, 421-432, doi:10.1139/t82-047, 1982.

Hansen, J., Sato, M., Ruedy, R., Kharecha, P., Lacis, A., Miller, R., Nazarenko, L., Lo, K., Schmidt, G. A., Russell, G., Aleinov, I., Bauer, S., Baum, E., Cairns, B., Canuto, V., Chandler, M., Cheng, Y., Cohen, A., Genio, A. D., Faluvegi, G., Fleming, E., Friend, A., Hall, T., Jackman, C., Jonas, J., Kelley, M., Kiang, N. Y., Koch, D., Labow, G., Lerner, J., Menon, S., Novakov, T., Oina, V., Perlwitz, J., Perlwitz, J., Rind, D., Romanou, A., Schmunk, R., Shindell, D., Stone, P., Sun, S., Streets, D., Tausnev, N., Thresher, D., Unger, N., Yao, M., and Zhang, S.: Climate simulations for 1880-2003 with GISS modelE, Clim. Dynam., 29, 661-696, doi:10.1007/s00382-007-0255-8, 2007.

Jackson, R. B., Sperry, J. S., and Dawson, T. E.: Root water uptake and transport: using physiological processes in global predictions, Trends Plant Sci., 5, 482-488, doi:10.1016/S13601385(00)01766-0, 2000.
Jiang, X., Niu, G.-Y., and Yang, Z.-L.: Impacts of vegetation and groundwater dynamics on warm season precipitation over the Central United States, J. Geophys. Res., 114, D06109, doi:10.1029/2008JD010756, 2009.

Koster, R. D. and Suarez, M. J.: Energy and Water Balance Calculations in the MOSAIC LSM, Technical Memorandum 1046069 , NASA, 1996.

Koven, C. D., Ringeval, B., Friedlingstein, P., Ciais, P., Cadule, P., Khvorostyanov, D., Krinner, G., and Tarnocai, C.: Permafrost carbon-climate feedbacks accelerate global warming, Proc. Natl. Acad. Sci., 108, 14769-14774, doi:10.1073/pnas.1103910108, 2011.

Krakauer, N. Y., Cook, B. I., and Puma, M. J.: Contribution of soil moisture feedback to hydroclimatic variability, Hydrol. Earth Syst. Sci., 14, 505-520, doi:10.5194/hess-14-505-2010, 2010.

Kustu, M. D., Fan, Y., and Robock, A.: Large-scale water cycle perturbation due to irrigation pumping in the US High Plains: A synthesis of observed streamflow changes, J. Hydrol., 390, 222244, doi:10.1016/j.jhydrol.2010.06.045, 2010.

Lam, A., Karssenberg, D., van den Hurk, B. J. J. M., and Bierkens, M. F. P.: Spatial and temporal connections in groundwater contribution to evaporation, Hydrol. Earth Syst. Sci., 15, 2621-2630, doi:10.5194/hess-15-2621-2011, 2011.

Lawrence, D. M., Slater, A. G., Romanovsky, V. E., and Nicolsky, D. J.: Sensitivity of a model projection of near-surface permafrost degradation to soil column depth and representation of soil organic matter, J. Geophys. Res., 113, F02011, doi:10.1029/2007JF000883, 2008.

Lawrence, D. M., Oleson, K. W., Flanner, M. G., Thornton, P. E., Swenson, S. C., Lawrence, P. J., Zeng, X., Yang, Z.-L., Levis, S., Skaguchi, K., Bonan, G. B., and Slater, A. G.: Parameterization improvements and functional and structural advances in version 4 of the Community Land Model, J. Adv. Model. Earth Syst., 3, M03001, doi:10.1029/2011MS000045, 2011.

Lee, J.-E., Oliveira, R. S., Dawson, T. E., and Fung, I.: Root functioning modifies seasonal climate, Proc. Natl. Acad. Sci., 102, 17576-17581, doi:10.1073/pnas.0508785102, 2005.

Lo, M.-H. and Famiglietti, J. S.: Precipitation response to land subsurface hydrologic processes in atmospheric general circulation model simulations, J. Geophys. Res., 116, D05107, doi:10.1029/2010JD015134, 2011.

Lo, M.-H., Famiglietti, J. S., Yeh, P. J.-F., and Syed, T. H.: Improving parameter estimation and water table depth simulation in a land surface model using GRACE water storage and estimated base flow data, Water Resour. Res., 46, W05517, doi:10.1029/2009WR007855, 2010.

Luo, Y. Q., Randerson, J. T., Abramowitz, G., Bacour, C., Blyth, E., Carvalhais, N., Ciais, P., Dalmonech, D., Fisher, J. B., Fisher, R., Friedlingstein, P., Hibbard, K., Hoffman, F., Huntzinger, D., Jones, C. D., Koven, C., Lawrence, D., Li, D. J., Mahecha, M., Niu, S. L., Norby, R., Piao, S. L., Qi, X., Peylin, P., Prentice, I. C., Riley, W., Reichstein, M., Schwalm, C., Wang, Y. P., Xia, J. Y., Zaehle, S., and Zhou, X. H.: A framework for benchmarking land models, Biogeosciences, 9, 3857-3874, doi:10.5194/bg-93857-2012, 2012.

Manabe, S.: Climate and the ocean circulation: I. The atmospheric circulation and the hydrology of the earth's surface, Mon. Weather Rev., 97, 739-774, doi:10.1175/15200493(1969)097<0739:CATOC>2.3.CO;2, 1969. 
Markewitz, D., Devine, S., Davidson, E. A., Brando, P., and Nepstad, D. C.: Soil moisture depletion under simulated drought in the Amazon: impacts on deep root uptake, New Phytol., 187, 592-607, doi:10.1111/j.1469-8137.2010.03391.x, 2010.

Matthews, E.: Global vegetation and land use: new high-resolution data bases for climate studies, J. Appl. Meteorol., 23, 474-487, doi:10.1175/1520-0450(1983)022<0474:GVALUN>2.0.CO;2, 1983.

Matthews, E.: Prescription of land-surface boundary conditions in GISS GCM II: A simple method based on fine-resolution data bases, Tech. Rep., NASA, 1984.

Maxwell, R. M., Chow, F. K., and Kollet, S. J.: The groundwater-land-surface-atmosphere connection: Soil moisture effects on the atmospheric boundary layer in fullycoupled simulations, Adv. Water Resour., 30, 2447-2466, doi:10.1016/j.advwatres.2007.05.018, 2007.

Miguez-Macho, G., Li, H., and Fan, Y.: Simulated water table and soil moisture climatology over North America, B. Am. Meteorol. Soc., 89, 663-672, 2008.

Milly, P. C. D. and Shmakin, A. B.: Global modeling of land water and energy balances. Part I: The Land Dynamics (LaD) model, J. Hydrometeorol., 3, 283-299, 2002.

Mock, J. E., Tester, J. W., and Wright, P. M.: Geothermal energy from the earth: its potential impact as an environmentally sustainable resource, Annual Review of Energy and the Environment, 22, 305-356, doi:10.1146/annurev.energy.22.1.305, 1997.

Nepstad, D. C., de Carvalho, C. R., Davidson, E. A., Jipp, P. H., Lefebvre, P. A., Negreiros, G. H., da Silva, E. D., Stone, T. A., Trumbore, S. E., and Vieira, S.: The role of deep roots in the hydrological and carbon cycles of Amazonian forests and pastures, Nature, 372, 666-669, doi:10.1038/372666a0, 1994.

Nicolsky, D. J., Romanovsky, V. E., Alexeev, V. A., and Lawrence, D. M.: Improved modeling of permafrost dynamics in a GCM land-surface scheme, Geophys. Res. Lett., 34, L08501, doi:10.1029/2007GL029525, 2007.

Niu, G.-Y., Yang, Z.-L., Dickinson, R. E., Gulden, L. E., and $\mathrm{Su}, \mathrm{H}$.: Development of a simple groundwater model for use in climate models and evaluation with Gravity Recovery and Climate Experiment data, J. Geophys. Res., 112, D07103, doi:10.1029/2006JD007522, 2007.

Oleson, K. W., Niu, G.-Y., Yang, Z.-L., Lawrence, D. M., Thornton, P. E., Lawrence, P. J., Stöckli, R., Dickinson, R. E., Bonan, G. B., Levis, S., Dai, A., and Qian, T.: Improvements to the Community Land Model and their impact on the hydrological cycle, J. Geophys. Res., 113, G01021, doi:10.1029/2007JG000563, 2008.

Pan, L., Jin, J., Miller, N., Wu, Y.-S., and Bodvarsson, G.: Modeling hydraulic responses to meteorological forcing: from canopy to aquifer, Vadose Zone J., 7, 325-331, doi:10.2136/vzj2006.0106, 2008.

Pollard, D., DeConto, R. M., and Nyblade, A. A.: Sensitivity of Cenozoic Antarctic ice sheet variations to geothermal heat flux, Global Planet. Change, 49, 63-74, doi:10.1016/j.gloplacha.2005.05.003, 2005.

Rayner, N. A., Parker, D. E., Horton, E. B., Folland, C. K., Alexander, L. V., Rowell, D. P., Kent, E. C., and Kaplan, A.: Global analyses of sea surface temperature, sea ice, and night marine air temperature since the late nineteenth century, J. Geophys. Res., 108, 4407, doi:10.1029/2002JD002670, 2003.
Roering, J. J., Marshall, J., Booth, A. M., Mort, M., and Jin, Q.: Evidence for biotic controls on topography and soil production, Earth Planet. Sci. Lett., 298, 183-190, doi:10.1016/j.epsl.2010.07.040, 2010.

Rosenzweig, C. and Abramopoulos, F.: Land-surface model development for the GISS GCM, J. Climate, 10, 2040-2054, doi:10.1175/1520-0442(1997)010;2040:LSMDFT i2.0.CO;2, 1997.

Sacks, W. J., Cook, B. I., Buenning, N., Levis, S., and Helkowski, J. H.: Effects of global irrigation on the near-surface climate, Clim. Dynam., 33, 159-175, doi:10.1007/s00382-008-0445-z, 2009.

Schmidt, G. A., Aleinov, I., Bell, N., Bauer, M., Bauer, S., Cairns, B., Faluvegi, G., Hu, Y., Kiang, N. Y., Koch, D., Lerner, J., Nazarenko, L., Perlwitz, J., Thresher, D., Ruedy, R., Cheng, Y., Lo, K. K., Oinas, V., Sato, M., Tausnev, N., Yao, M.-S., Hansen, J. E., Canuto, V., Genio, A. D., Hall, T. M., Lacis, A. A., Miller, R. L., Rind, D., Russell, G. L., Shindell, D. T., Friend, A. D., Kelley, M., Romanou, A., Perlwitz, J., and Stone, P. H.: Presentday atmospheric simulations using GISS ModelE: comparison to in situ, satellite, and reanalysis data, J. Climate, 19, 153-192, doi:10.1175/JCLI3612.1, 2006.

Schwinning, S.: The ecohydrology of roots in rocks, Ecohydrology, 3, 238-245, doi:10.1002/eco.134, 2010.

Seneviratne, S. I., Corti, T., Davin, E. L., Hirschi, M. Jaeger, E. B., Lehner, I., Orlowsky, B., and Teuling, A. J.: Investigating soil moisture-climate interactions in a changing climate: A review, Earth-Sci. Rev., 99, 125-161, doi:10.1016/j.earscirev.2010.02.004, 2010.

Siebert, S., Burke, J., Faures, J. M., Frenken, K., Hoogeveen, J., Döll, P., and Portmann, F. T.: Groundwater use for irrigation - a global inventory, Hydrol. Earth Syst. Sci., 14, 1863-1880, doi:10.5194/hess-14-1863-2010, 2010.

Stöckli, R., Lawrence, D. M., Niu, G.-Y., Oleson, K. W., Thornton, P. E., Yang, Z.-L., Bonan, G. B., Denning, A. S., and Running, S. W.: Use of FLUXNET in the Community Land Model development, J. Geophys. Res., 113, G01025, doi:10.1029/2007JG000562, 2008.

Stone, E. L. and Kalisz, P. J.: On the maximum extent of tree roots, Forest Ecol. Manage., 46, 59-102, 1991.

Subin, Z. M., Koven, C. D., Riley, W. J., Torn, M. S., Lawrence, D. M., and Swenson, S. C.: Effects of soil moisture on the responses of soil temperatures to climate change in cold regions, J. Climate, 26, 3139-3158, doi:10.1175/JCLI-D-12-00305.1, 2013.

Sutanudjaja, E. H., van Beek, L. P. H., de Jong, S. M., van Geer, F. C., and Bierkens, M. F. P.: Large-scale groundwater modeling using global datasets: a test case for the Rhine-Meuse basin, Hydrol. Earth Syst. Sci., 15, 2913-2935, doi:10.5194/hess-152913-2011, 2011

Tiwari, V. M., Wahr, J., and Swenson, S.: Dwindling groundwater resources in northern India, from satellite gravity observations, Geophys. Res. Lett., 36, L18401, doi:10.1029/2009GL039401, 2009.

Tóth, J.: A theoretical analysis of groundwater flow in small drainage basins, J. Geophys. Res., 68, 4795-4812, 1963.

Vergnes, J.-P. and Decharme, B.: A simple groundwater scheme in the TRIP river routing model: global off-line evaluation against GRACE terrestrial water storage estimates and observed river discharges, Hydrol. Earth Syst. Sci., 16, 3889-3908, 
doi:10.5194/hess-16-3889-2012, 2012.

Werth, S. and Güntner, A.: Calibration analysis for water storage variability of the global hydrological model WGHM, Hydrol. Earth Syst. Sci., 14, 59-78, doi:10.5194/hess-14-59-2010, 2010.

Zeng, X. and Decker, M.: Improving the numerical solution of soil moisture-based Richards equation for land models with a deep or shallow water table, J. Hydrometeorol., 10, 308-319, doi:10.1175/2008JHM1011.1, 2009.
Zhang, T., Heginbottom, J. A., Barry, R. G., and Brown, J.: Further statistics on the distribution of permafrost and ground ice in the Northern Hemisphere, Polar Geography, 24, 126-131, doi:10.1080/10889370009377692, 2000. 